Jurnal PG-PAUD Trunojoyo : Jurnal Pendidikan dan Pembelajaran Anak Usia Dini, Volume 7, Nomor 2, Oktober 2020 hal 9-22, ISSN : 2528-3553 (online), ISSN: 2407-4454 (print)

\title{
STRATEGI PEMBELAJARAN OUTING CLASS GUNA MENINGKATKAN ASPEK PERKEMBANGAN ANAK USIA DINI
}

\author{
Rizka Lailatul Rahmawati ${ }^{1}$ \\ Fikri Nazarullail $^{2}$ \\ 1,2PG-PAUD, Universitas Trunojoyo Madura \\ Email: rizkarahmawati09@gmail.com, fikri.nazarullail@,trunojoyo.ac.id \\ Received (Juni), Accepted (September), Published (Oktober)
}

\begin{abstract}
Learning Strategies Through Outing Classes to Improve Aspects of Child Development. Learning is an important thing that is done in an educational process. Therefore, an appropriate learning strategy is needed. The learning strategy that can be done is through outing class activities. Outing class activities can also help improve aspects of child development because one of the goals of early childhood learning strategies is to improve aspects of child development. The purpose to be achieved in this article is to determine the effect and learning outcomes of early childhood through outing class activities. The method used in this article is to use the idea of thinking or this article is a scientific work which is nonresearch, so that it is an organized and systematic thought. The result of this idea of thinking is that outing class learning strategies can help in fostering interest in learning in children. In the new normal era, this strategy is suitable to be applied in learning because it can eliminate learning boredom in children during the Covid-19 pandemic, provided that students are obliged to adhere to health protocols.
\end{abstract}

Keywords: learning strategy, outing class, aspects of child development.

Abstrak: Strategi Pembelajaran Melalui Outing Class Guna Meningkatkan Aspek Perkembangan Anak. Pembelajaran merupakan suatu hal penting yang dilakukan dalam sebuah proses pendidikan. Oleh karena itu dibutuhkan strategi pembelajaran yang tepat. Adapun strategi pembelajaran yang dapat dilakukan adalah melalui kegiatan outing class. Kegiatan outing class juga dapat membantu meningkatkan aspek perkembangan anak karena salah satu tujuan strategi pembelajaran anak usia dini adalah meningkatkan aspek perkembangan anak. Tujuan yang hendak dicapai dalam artikel ini adalah mengetahui pengaruh dan hasil pembelajaran pada anak usia dini melalui kegiatan outing class. Adapun metode yang digunakan dalam artikel ini adalah menggunakan gagasan berpikir atau artikel ini merupakan karya ilmiah yang termasuk non penelitian, sehingga di dalamnya merupakan gagasan berpikir yang terorganisir dan sistematik. Hasil dari gagasan berfikir ini adalah strategi pembelajaran outing class dapat membantu dalam menumbuhkan minat belajar pada anak. Pada era new normal, strategi ini cocok di terapkan di dalam pembelajaran karena dapat menghilangkan kejenuhan belajar pada anak anak selama masa pandemi covid-19 dengan syarat peserta didik wajib untuk tetap mematuhi protokol kesehatan.

Kata Kunci: strategi pembelajaran, outing class, aspek perkembangan anak usia dini

Copyright (c) 2020 Rizka Lailatul Rahmawati, Fikri Nazarullail 
Jurnal PG-PAUD Trunojoyo : Jurnal Pendidikan dan Pembelajaran Anak Usia Dini, Volume 7, Nomor 2, Oktober 2020 hal 9-22, ISSN : 2528-3553 (online), ISSN: 2407-4454 (print)

\section{PENDAHULUAN}

Proses pendidikan di masa new normal ini dilakukan secara daring yang semula dilakukan secara konvensional, dan saat ini kegiatan pembelajaran tersebut dilakukan secara daring (dalam jaringan). Beberapa cara diterapkan untuk menunjang pendidikan di masa new normal ini, salah satu cara yang diterapkan adalah kegiatan pembelajaran yang dilakukan secara daring menggunakan media sosial dan aplikasi Learning Managemen System (LMS) yang awalnya dilakukan secara luring (luar jaringan) atau tatap muka (Wulandari, H \& Purwanta, E, 2020). Kegiatan pembelajaran secara daring merupakan anjuran dari Pemerintah dan Kementerian Pendidikan dan Kebudayaan. Kebijakan tersebut diterapkan oleh seluruh satuan pendidikan formal yang dimulai dari pendidikan pra-sekolah yang terdiri dari Kelompok Bermain dan Taman Kanak-kanak, Sekolah Dasar dan Menengah serta Pendidikan Tinggi. Menurut (Herliandry dkk., 2020) menjelaskan bahwa pembelajaran daring (online) menjadikan pengalaman baru bagi pendidik serta peserta didik dalam melaksanakan kegiatan pembelajaran dengan model yang baru untuk melaksanakan protokol kesehatan.

Proses belajar mengajar dengan sistem pembatasan sosial pasti membutuhkan strategi pembelajaran yang tepat dan efisien. Menurut (Yaumi, 2013) Strategi pembelajaran adalah segala usaha guru untuk menerapkan berbagai metode pembelajaran dalam mencapai tujuan yang diharapkan. Dengan demikian strategi pembelajaran menekankan kepada bagimana aktivitas guru mengajar dan aktivitas anak belajar. Sedangkan menurut Fadlillah (2012) mengemukakan strategi pembelajaran dapat diratikan sebagai kegiatan merencanakan pembelajaran yang berisi tentang rangkaian kegiatan yang harus dilakukan guru dan murid, termasuk di dalamnya penggunaan metode dan pemanfaatan sumber daya untuk mencapai tujuan pembelajaran yang efektif dan efisien.

Strategi pembelajaran ini juga dapat mempermudah para guru dalam melaksanakan kegiatan mengajar karena sebelumnya sudah merencanakan dan menyusun strategi pembelajaran. Meskipun strategi pembelajaran sangat penting namun kesiapan guru dalam melaksanakan pembelajaran daring juga sangat penting guna menunjang pembelajaran (Ayuni, D. dkk. 2020).

Salah satu inovasi strategi pembelajaran yang dapat diterapkan ke anak dan menarik minat belajar adalah menggunakan strategi pembelajaran outing class. Outing class merupakan proses pembelajaran yang dilakukan di luar ruangan. Kegiatan outing class ini menjadikan anak mendapatkan pengalaman dan pengetahuan baru serta belajar berinteraksi dengan lingkungan dan alam secara langsung (Maryanti, S. dkk, 2019). Selain itu juga, outing class membantu meningkatkan aspek perkembangan pada anak. Oleh karena itulah strategi outing class ini akan sangat efektif untuk meningkatkan partisipasi belajar pada peserta didik dengan syarat kondisi pandemi Covid-19 dikatakan aman dan dapat dilaksanakan pembelajaran tatap muka seperti sedia kala.

Mengingat pentingnya peningkatan aspek perkembangan anak dimasa pandemi kurang berkembang secara efektif, maka penerapan strategi pembelajaran melalui outing class merupakan salah satu kegiatan pembelajaran yang tepat diterapkan ke anak ketika pembelajaran tatap muja berjalan normal seperti biasa. Melalui kegiatan outing class, anak-anak secara langsung dapat mengexplorasi lingkungan. Hal itu dapat menghilangkan kejenuhan anak saat proses belajar mengajar berlangsung. Strategi pembelajaran outing class ini dapat menjadikan kegiatan pembelajaran lebih menyenangkan bagi anak. Anak-anak bisa 
Jurnal PG-PAUD Trunojoyo : Jurnal Pendidikan dan Pembelajaran Anak Usia Dini, Volume 7, Nomor 2, Oktober 2020 hal 9-22, ISSN : 2528-3553 (online), ISSN: 2407-4454 (print)

mendapatkan pengetahuan yang luas dan lansung dari proses interaksi langsung terhadap lingkungan dan alam sekitar.

Menurut Adelia Vera (2012) mengajar di luar kelas secara khusus adalah kegiatan belajar mengajar antara guru dan murid, namun tidak dilakukan di dalam kelas, tetapi dilakukan dilakukan di luar kelas atau alam terbuka sebagai kegiatan pembelajaran siswa. Metode mengajar di luar kelas juga dipahami sebagai sebuah pendekatan pembelajaran terhadap berbagai permainan, sebagai media transformasi konsep-konsep yang disampaikan dalam pelajaran.

Outing class adalah suatu kegiatan yang melibatkan alam secara langsung untuk dijadikan sebagai sumber belajar (Vera, 2012). Outing class merupakan salah satu cara yang digunakan sebagai upaya mendekatkan diri anak terhadap kehidupan yang sesungguhnya yaitu lingkungan masyarakat. Kegiatan outing class yang dilaskanakan adalah dengan mengajak anak-anak ke luar ruangan ke tempat yang di telah direncanakan untuk tujuan kegiatan pembelajaran maupun aktivitas lain yang bertujuan untuk mengembangkan aspek perkembangan anak usia dini.

Menurut (Wulandari, H \& Purwanta, E, 2020) menjelaskan bahwa selama pandemi Covid-19 kegiatan pembelajaran daring menimbulkan tingkat perkembangan anak usia dini menjadi kurang berkembang secara signifikan terutama pada aspek sosial dan emosional anak. Penelitian tersebut menunjukkan bahwa perkembangan sosial emosional anak kurang berkembang selama pandemi Covid-19 ini. Oleh karena itu, interaksi antar anak dengan lingkungan perlu distimulasi dengan baik dengan tetap menjaga protokol kesehatan.

Salah satu kegiatan outing class yang sering dilakukan adalah dengan mengunjungi kebun binatang, pantai, dan kolam renang, dan playgorund. Kegiatan belajar dengan strategi outing class dengan pembelajaran kontekstual juga bisa mengadakan kunjungan ke puskesmas, kantor polisi, kantor pos, kantor pemadam kebakaran, perusahaan dan lain sebagainya. Selama melakukan kegiatan outing class anak-anak dapat bermain sambil belajar. Melalui kegiatan outing class juga anak-anak tidak hanya duduk diam mendengarkan penjelasan guru tetapi juga bergerak aktif dan bebas sesuai dengan kemampuan mengekplorasi lingkungan yang mereka kunjungi.

Selama pandemi Covid-19, pembelajaran yang dilakukan belum bisa berjalan dengan maksimal. Hal tersebut membuat menurunnya aktivitas belajar anak dan berpengaruh pada penurunan aspek perkembangan anak terutama pada aspek sosial emosional (Wulandari, H \& Purwanta, E, 2020). Bagi Sebagian anak, belajar merupakan suatu hal yang membosankan. Oleh karena itu, dalam artikel ini penulis memberikan gagasan tentang aktivitas belajar yang dilakukadi luar ruang belajar anak sehari-hari outing class agar pembelajaran dapat lebih bermakna bagi anak. Kegiatan yang dilakukan melalui outing class ini dapat membantu meningkatkan semangat belajar anak yang kemudian berpengaruh pada proses peningkatan aspek perkembangan anak.

\section{METODE PENELITIAN}

Metode yang digunakan dalam penelitian ini adalah studi pustaka yang terorganisir dan sistematik. Artikel ini menelaah beberapa prinsip, suatu konsep, maupun beberapa teori. Pembahasan maupun isi dari gagasan berpikir ini berdasarkan pada studi literatur seperti pada jurnal, buku, serta artikel-artikel ilmiah yang sudah terbukti keaslian dan kredibilitasnya.

\section{HASIL DAN PEMBAHASAN}

Strategi pembelajaran outing class mampu memberikan dampak positif bagi perkembangan dan peningkatan kemauan belajar anak. Di masa new normal seperti 
Jurnal PG-PAUD Trunojoyo : Jurnal Pendidikan dan Pembelajaran Anak Usia Dini, Volume 7, Nomor 2, Oktober 2020 hal 9-22, ISSN : 2528-3553 (online), ISSN: 2407-4454 (print)

sekarang ini, menerapkan strategi pembelajaran adalah pilihan yang sangat menarik bagi kegiatan pembelajara untuk anak-anak setelah menjalani masa pembelajaran daring di dalam rumah. Strategi ini juga berdampak baik bagi kesehatan anak karena anak dapat beraktivitas diluar dan berkontak dengan sinar matahari secara langsung sehingga menyebabkan keluarnya keringat dari tubuh dan menjadikan tubuh sehat serta bugar. Namun pada saat ini kegiatan pembelajaran dengan strategi outing class masih belum dapat diterapkan secara maksimal mengingat adanya pembatasan aktivitas untuk mengurangi dampak menyebarnya Covid-19. Oleh karena itu gagasan ini ditujukan bagi pendidik untuk melaksanakan kegiatan pembelajaran pada saat aktivitas belajar dan bermain sudah normal kembali.

\section{Hakikat outing class dalam perkembangan Pendidikan}

Outing class merupakan kegiatan belajar mengajar yang menyenangkan. Kegiatan pembelajaran dapat dikatakan pembelajaran yang menyenangkan karena kegiatan bermain bersifat sukarela dan menimbulkan rasa senang pada anak-anak (Rindani, 2017). Melalui bermain, kegiatan pembelajaran yang semula terasa jenuh bagi anak-anak berubah menjadi kegiatan pembelajaran yang menyenangkan dengan bermain. Kegiatan belajar mengajar tidak dilakukan di dalam ruangan seperti pada umumnya tetapi dilakukan di luar ruangan. Kegiatan tersebut lebih mendekatkan anak terhadap lingkungan. Kegiatan outing class juga dapat membantu meningkatkan aspek perkembangan anak. Outing class adalah kegiatan belajar yang berhubungan langsung dengan lingkungan atau alam. Pembelajaran di luar kelas atau outing class adalah suatu kegiatan yang melibatkan alam secara langsung untuk dijadikan sumber belajar (Vera, 2012:17).
Kegiatan outing class dilakukan di luar ruangan. Kegiatan outing class melibatkan anak-anak dan guru sebagai subjek kegiatan. Outing class menjadikan pembelajaran lebih menyenangkan.

Outing class merupakan suatu kegiatan pembelajaran yang dilaksanakan di luar ruangan atau kelas yang bertujuan untuk membekali keterampilan peserta didik dan mengembangkan kemampuan yang dimiliki (Dina Indriana, 2011). Untuk mengadakan pembelajaran di luar kelas, guru harus teliti dalam menentukan tepat kegiatan yang akan dilakukan sebagai tempat kegiatan outing class. tempat kegiatan outing class hendaknya adalah tempat yang strategis dan efektif untuk dilakukan pembelajaran. Secara umum, terdapat dua lokasi yang dapat digunakan sebagai tempat kegiatan kegiatan outing class, yakni lingkungan di dalam sekolah dan lingkungan di luar sekolah. lokasi pertama yaitu lingkungan sekolah. lingkungan sekolah merupakan tempat kegiatan outing class yang cukup efektif karena tidak perlu membutuhkan banyak biaya untuk pergi keluar, tidak memerlukan waktu banyak untuk menuju tempat kegiatan pembelajaran namun pembelajaran tetap efektif dilakukan. Adapun lokasi lingkungan sekolah yang dapat dijadikan sebagai tempat kegiatan outing class, anatara lain:

a) Halaman sekolah

b) Taman bunga di sekolah

c) Pohon-pohon yang ada di halaman sekolah

d) Halaman belakang sekolah

e) Lapangan sekolah

f) Koperasi sekolah

g) Kolam yang ada di area sekolah

Dari paparan di atas mengenai lingkungan sekolah yang dapat digunakan sebagai kegiatan outing class tidak semua sekolah memliki objek-objek yang telah disebutkan di atas. Oleh karena itu, di 
Jurnal PG-PAUD Trunojoyo : Jurnal Pendidikan dan Pembelajaran Anak Usia Dini, Volume 7, Nomor 2, Oktober 2020 hal 9-22, ISSN : 2528-3553 (online), ISSN: 2407-4454 (print)

dalam artikel ini penulis menuliskan bentuk kegiatan outing class yang dapat digunakan yaitu di halaman belakang sekolah atau kebun yang ada di sekolah melalui kegiatan bercocok tanam. Guru dapat memanfaatkan sebagai tempat bercocok tanam dengan kondisi yang tidak jauh dari sekolah. Melalui bercocok tanam anak-anak dapat berinteraksi langsung dengan alam dan itu membuat anak-anak merasa senang dan menghindarkan anak dari kejebuhan saat belajar dalam kelas. Jadi, kegiatan outing class bercocok tanam di halaman belakang sekolah cukup efektif dilakukan karena letak halaman yang tidak jauh dari sekolah. Kegiatan bercocok tanam juga dilakukan dengan tetap mematuhi protokol kesehatan. Kegiatan tersebut dapat dilakukan sesuai dengan waktu yang telah direncanakan. Jadi, kegiatan outing class bercocok tanam tetap bisa dilakukan dengan tetap mematuhi protokol kesehatan. Di masa new normal ini sekolah sudah mulai di buka meskipun tidak seluruh sekolah yang membuka belajar mengajar secara tatap muka langsung. Pada Lembaga PAUD ini sekolah ada yang telah dibuka meskipun masuk ke sekolah hanya seminggu sekali. Jadi, untuk penerapan kegiatan outing class bercocok tanam ini cukup aman dilakukan saat proses belajar mengajar.

Lokasi kedua yang dapat dijadikan sebagai tempat kegiatan outing class adalah lingkungan di luar sekolah. lingkungan di luar sekolah ini dapat memberikan dampak positif terhadap kecerdasan anak dan dapat berpengaruh terhadap meningkatnya aspek perkembangan anak. Adapun tempat yang dapat digunakan sebagai tempat kegiatan outing class antara lain:
a) Area sawah
b) Kebun binatang

c) Museum

d) Perusahaan

e) Pantai

f) Area kebun

g) Pegunungan

h) Tempat ibadah

i) Taman

j) Cagar alam

k) Tempat pariwisata

1) Kendang hewan

Selain tempat-tempat yang telah di sebutkan di atas, masih ada banyak lagi tempat yang dapat digunakan sebagai kegiatan outing class di lingkungan luar sekolah. Namun, tidak semua tempat yang ada di lingkungan luar sekolah dapat dijadikan sebagai tempat pembelajaran. Jadi, guru juga harus selektif dalam memilih tempat yang akan dijadikan sebagai objek pembelajaran.

Bentuk-bentuk pembelajaran outing class:

1. Jelajah Alam Sekitar

Manusia hidup di bumi itu bergantung pada alam, jadi tidak heran juga jika anak-anak suka bermain yang ada kaitannya dengan alam. Benda yang sering digunakan anak untuk alat bermain adalah tanah dan pasir.

2. Perkemahan

Perkemahan adalah kegiatan yang dilakukan di luar ruangan yang dapat membantu pembentukan karakter anak-anak. Untuk melakukan kegiatan perkemahan ini harus dilakukan perencanaan yang matang supaya kegiatan dapat berjalan lancar.

3. Karyawisata

Dalam KBBI karyawista bermakna kunjungan ke suatu objek dalam rangka memperluas pengetahuan dalam hubungan dengan pekerjaan seseorang atau sekelompok. Karyawista atau yang sering disebut field trip merupakan kegiatan yang 
Jurnal PG-PAUD Trunojoyo : Jurnal Pendidikan dan Pembelajaran Anak Usia Dini, Volume 7, Nomor 2, Oktober 2020 hal 9-22, ISSN : 2528-3553 (online), ISSN: 2407-4454 (print)

dilaksanakan tidak hanya sekedar jalan-jalan tetapi juga belajar dan beradaptasi dengan lingkungan.

Dalam melakukan kegiatan outing class perlu adanya persiapan dan perencanaan dalam melakukan kegiatan tersebut. Berikut penjelasan mengenai langkah-langkah melakukan kegiatan outing class:

a. Perencanaan outing class:

1)Merumuskan tujuan outing class;

2)Menetapkan objek yang sesuai dengan tujuan yang hendak dicapai;

3)Menetapkan durasi waktu outing class;

4)Merencanakan perlengkapan belajar yang harus disediakan;

b. Pelaksanaan outing class:

Pada tahap ini adalah pelaksanaan kegiatan belajar di tempat yang telah direncanakan dengan bimbingan guru. Kegiatan belajar ini harus diarahkan kepada tujuan yang telah ditetapkan pada tahap perencanaan di atas. Pelaksanaan kegiatan outing class ini juga harus memperhatikan rencana pembelajaran dan tema kegiatan pembelajaran. Karena dengan menyesuaikan dengan panduan kurikulum yang telah disusun oleh lembaga maka kegiatan outing class yang dilakukan sesuai dengan capaian pembelajaran yang ingin dicapai.

c. Tindak lanjut

Pada akhir kegiatan outing class siswa diminta untuk menyampaikan secara lisan (bercerita), mengenai apa yang telah mereka pelajari pada waktu karyawisata/outbound/studi visit.

d. Tahap evaluasi

Jika siswa tidak memberikan jawaban maka guru tidak mengatakan salah tetapi menyebutkan kata yang benar dan mengajak siswa untuk mengulangi kembali (Abdurrahman, 1995: 11).

Proses penerapan outing class memiliki dampak serta manfaat yang cukup signifikat dalam perkembangan anak-anak. Strategi ini mempunyai beberapa keunggulan, yaitu mendorong siswa untuk belajar lebih aktif dan ikut berperan dalam kegiatan belajar mengajar, menerapkan konsep belajar sambil berekreasi (learning by doing and refreshing), dapat menghilangkan rasa jenuh selama belajar di dalam kelas dan dapat mengembangkan kehidupan demokrasi dalam dunia pendidikan (Suherman dan Udin, 2002: 312)

Adapun manfaat dari penerapan pembelajaran outing class, antara lain:

a. Mengurangi rasa jenuh saat proses belajar mengajar secara daring maupun tatap muka/konvensional.

b. Melatih anak untuk memiliki sikap sosial dan bekerja sama ketika terdapat pembentukan kelompok

c. Meningkatkan kreatifitas anak

d. Meningkatkan moralitas anak untuk disiplin

e. Menambah kecintaaan anak terhadap lingkungan terutama makhluk Tuhan Yang Maha Esa

f. Meningkatkan kemampuan bahasa dalam bercerita

Lickona (1991) mengemukakan bahwa pendidikan nilai/moral yang meghasilkan karakter, didalamnya terkandung tiga komponen karakter yang baik (components of good character), yakni pengetahuan tentang moral (moral knowing), perasaan tentang moral (moral feeling), dan perbuatan moral (action moral). Pembelajaran outing class juga sangat penting untuk mengembangkan tiga komponen Pendidikan pada anak. Ketiga komponen tersebut, antara lain:

\section{a. Afektif (Perasaan)}

Afektif yaitu munculnya perasaan senang, sedih, tertawa, atau menangis yang dialami oleh seseorang.

b. Kognitif (Pikiran) 
Jurnal PG-PAUD Trunojoyo : Jurnal Pendidikan dan Pembelajaran Anak Usia Dini, Volume 7, Nomor 2, Oktober 2020 hal 9-22, ISSN : 2528-3553 (online), ISSN: 2407-4454 (print)

Kognitif adalah proses berfikir seseorang terhadap sesuatu yang dipikirkan.

c. Psikomotorik (Tindakan fisik)

Psikomotorik adalah kemampuan bertindak pada diri seseorang setelah mereka mendapatkan pengalaman belajar mengenai suatu hal.

Pendidikan dikatakan berjalan dengan baik apabila terdapat komponen yang membantu melancarkan kegiatan Pendidikan itu sendiri, diantaranya yang pertama adalah tujuan pembelajaran yang merupakan arah atau haluan kegiatan belajar yang ingin dicapai melalui suatu proses belajar mengajar. selanjutnya adalah faktor pendidik, dimana seorang pendidik harus memiliki kompetensi yang wajib dimiliki dan mampu untuk mengaplikasikannya. Yang terakhir adalah peserta didik, dimana seorang peserta didik merupakan bagian dari masyarakat yang mencari ilmu dan pengalaman baru untuk menyongsong kehidupan di masa depannya.

Berdasarkan penjelasan di atas mengenai tiga komponen pendidikan merupakan hal penting dalam Pendidikan. Ketiganya berkaitan satu sama lain. apabila ketiganya tidak lengkap, maka pendidikan tidak akan berjalan dengan lancar.

\section{Strategi Pembelajaran Outing Class}

Strategi merupakan langkah-langkah yang telah dirancang secara khusus dalam jangka waktu panjang pada sebuah organisasi atau intitusi atau lembaga untuk mencapai serangkaian tujuan yang telah direncanakan. Strategi merupakan suatu proses yang melewati tahap perencanaan, pelaksanaan, dan pengeksekusian sebuah aktivitas dalam jangka waktu tertentu. Dengan demikian, hampir seluruh aktivitas membutuhkan strategi yang tepat dalam menjalankan segala aktivitasnya.
Pembelajaran melalui outing class bisa merujuk ke beberapa tema pembelajaran yang ada di PAUD, diantaranya tema lingkunganku, profesi, tanaman, binatang, udara air dan api. Kegiatan outing class dapat dilaksanakan sesuai dengan kebutuhan pembelajaran. Kegiatan outing class merupakan kegiatan pembelajaran yang sangat cocok diterapkan kepada anak untuk membantu meningkatkan aspek perkembangan yang dimilikinya.

Kegiatan outing class tidak harus pergi keluar ke tempat yang membutuhkan banyak biaya, tetapi bisa dilakukan dengan hal sederhana seperti diajak ke kebun sekolah, halaman sekolah, kendang ternak milik warga terdekat, kebun sayuran milik warga terdekat, dan lain sebagainya. Hal itu tidak terlalu membutuhkan banyak biaya namun pembelajaran dapat berjalan efektif serta tidak memakan waktu banyak saat diperjalanan. Kegiatan outing class ini dapat dilakukan beberapa bulan sekali sesuai dengan tema pembelajaran.

Bentuk kegiatan dari outing class diantaranya dapat berupa outbond, kunjungan pada instansi tertentu dan mengajak peserta didik jalan-jalan untuk melihat lingkungan sekitar. Kegiatan outbond sendiri juga dapat membantu meningkatkan perkembangan psikomotorik anak. Pengembangan secara psikomotorik dapat melalui proses pembelajaran di luar maupun di dalam kelas (Ratih, K., et al, 2019). Menurut Djamaluddin Ancok (2003) bahwa outbond adalah kegiatan di alam terbuka (outdoor), outbond juga dapat memacu semangat belajar. Outbond merupakan sarana pembelajaran yang kegiatannya berpetualang sehingga memacu anak untuk semangat dan kreatif. Bentuk kegiatan outbond adalah permainan (games) yang kreatif, rekreatif, edukatif. 
Jurnal PG-PAUD Trunojoyo : Jurnal Pendidikan dan Pembelajaran Anak Usia Dini, Volume 7, Nomor 2, Oktober 2020 hal 9-22, ISSN : 2528-3553 (online), ISSN: 2407-4454 (print)

Kegiatan outbond dapat dilakukan secara individu ataupun berkelompok.

Berdasarkan pemaparan di atas, maka pembelajaran outing class merupakan salah satu upaya pembelajaran yang dilakukan ke anak dengan mengajaknya ke luar kelas atau ke lingkungan sekitar sebagai proses pendekatan anak ke masyarakat maupun lingkungan sekitar. Jadi, proses belajar mengajar tidak hanya dilakukan di dalam kelas tetapi dapat juga dilakukan di luar kelas sesuai dengan cakupan materi yang telah dirancang. Hal itu dapat menambah semangat belajar anak dan membuat anak merasa lebih senang dalam belajar. Selain itu juga dapat menambah pengetahuan dan pengalaman anak terhadap lingkungan luar kelas. Sehingga, pembelajaran di luar kelas sangat berpengaruh terhadap aspek perkembangan anak.

Kegiatan outing class dilaksanakan tentunya mempunyai tujuan yang jelas. Kegiatan outing class tidak hanya untuk bersenang-senang tetapi mempunyai tujuan yang ingin dicapai. Adapun tujuan pembelajaran melalui outing class menurut (Indriana, 2011: 59) sebagai berikut:

a. Strategi ini dapat mengidentifikasi berbagai kekuatan dan kelemahan pada diri anak didik.

b. Anak didik yang mengikuti kegiatan outing class dapat mengeluarkan segala ekspresi dan potensi yang ada dalam diri dengan caranya sendiri namun tetap dalam aturan dalam permainan.

c. Pembelajaran outing class akan menjadikan anak didik dapat menghargai dan menghormati diri sendiri dan orang lain.

d. Anak didik akan mampu belajar dengan menyenangkan sehingga anak didik akan terus termotivasi dan bersemangat untuk melakukan segala kegiatan. e. Outing class akan memupuk jiwa kemandirian anak didik untuk melakukan segala rangkaian kegiatan dengan mengeluarkan segala potensi yang ada dalam dirinya, sehingga mampu menyelesaikan dengan hasil yang maksimal.

f. Akan menumbuhkan sikap dan empati terhadap perasaan orang lain, karena kegiatan ini dilakukan secara berkelompok.

g. Outing class juga mengajarkan anak didik untuk dapat berkomunikasi dengan orang lain di sekitar.

h. Anak didik mampu mengetahui cara yang efektif dan kreatif.

i. Outing class juga menjadi sarana yang tepat untuk membangun karakter atau kepribadian anak yang baik.

j. Anak didik bisa memahami nilai positif melalui berbagai contoh nyata dalam kegiatan outing class yang dilaksanakan.

Kegiatan outing class juga memiliki manfaat bagi orang-orang yang terlibat dalam kegiatan outing class tersebut. Adapun manfaat kegiatan outing class menurut Dina Indriana (201) sebagai berikut:

a. Menambah pengetahuan anak tentang alam sekitar.

b. Menambah kecintaan anak terhadap alam sekitar.

c. Mengurangi kejenuhan anak dalam belajar.

d. Menjadikan anak mudah untuk menerima informasi.

e. Menambah kepedulian anak tentang alam sekitar.

f. Meningkatkan kemampuan anak dalam bercerita.

g. Merangsang kreativitas anak.

h. Menambah pengetahuan guru dalam merencanakan strategi pembelajaran. 
Jurnal PG-PAUD Trunojoyo : Jurnal Pendidikan dan Pembelajaran Anak Usia Dini, Volume 7, Nomor 2, Oktober 2020 hal 9-22, ISSN : 2528-3553 (online), ISSN: 2407-4454 (print)

\section{Aspek Perkembangan yang Terbentuk Melalui Outing Class}

Tabel 1. Capaian aspek perkembangan

\begin{tabular}{|c|c|}
\hline No. & Uraian capaian \\
\hline 1. & 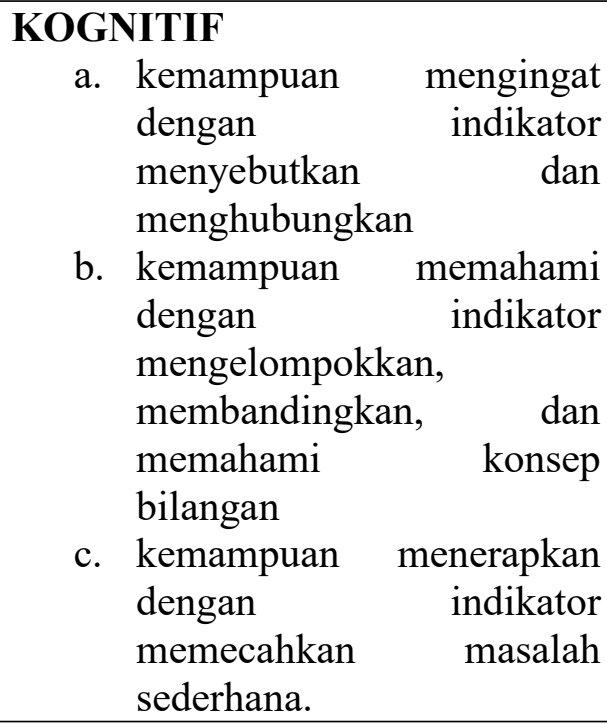 \\
\hline 2. & $\begin{array}{l}\text { FISIK MOTORIK } \\
\text { a. Anak-anak dapat } \\
\text { memegang benda yang } \\
\text { aman untuk dipegang oleh } \\
\text { anak-anak dan merasakan. }\end{array}$ \\
\hline 3. & $\begin{array}{l}\text { BAHASA } \\
\text { a. Anak-anak akan bertanya } \\
\text { mengenai hal yang belum } \\
\text { diketahui } \\
\text { b. anak-anak akan belajar } \\
\text { bercerita atau menceritakan } \\
\text { kembali tentang apa yang } \\
\text { mereka lihat maupun } \\
\text { tentang pengalaman } \\
\text { mereka saat melakukan } \\
\text { kegiatan outing class di } \\
\text { depan kelas atau di tempat } \\
\text { yang sudah disediakan } \\
\text { guru. }\end{array}$ \\
\hline 4. & $\begin{array}{l}\text { SOSIAL EMOSIONAL } \\
\text { a. Anak-anak belajar bersabar } \\
\text { dan mengantri dalam } \\
\text { proses belajar mengajar. }\end{array}$ \\
\hline
\end{tabular}

\begin{tabular}{|c|c|}
\hline & $\begin{array}{l}\text { b. Anak-anak dapat bekerja } \\
\text { sama untuk melakukan } \\
\text { kegiatan yang } \\
\text { membutuhkan kerja sama }\end{array}$ \\
\hline 5. & $\begin{aligned} \text { ENI } & \\
\text { a. } & \text { Anak dapat } \\
& \text { menggambarkan tentang } \\
& \text { hal yang telah di dapat dari } \\
& \text { kegiatan outing class. } \\
\text { b. Anak-anak belajar } & \text { menempel gambar dari } \\
& \text { proses kegiatan outing } \\
& \text { class. }\end{aligned}$ \\
\hline 6. & $\begin{array}{l}\text { NILAI AGAMA MORAL } \\
\text { a. Anak-anak belajar } \\
\text { mensyukuri tentang apa } \\
\text { yang sudah di ciptakan } \\
\text { Tuhan. Bagi yang muslim } \\
\text { dapat dengan mengucap } \\
\text { Alhamdulillah dan bagi } \\
\text { yang non muslim dapat } \\
\text { menyesuaikannya. }\end{array}$ \\
\hline
\end{tabular}

Selain penjelasan tentang dampak outing class tersebut, outing class juga dapat membantu meningkatkan semangat belajar anak sehingga berdampak pada kualitas aspek perkembangan anak. Aspek perkembangan merupakan hal penting dalam proses pembelajaran. Dalam melakukan pembelajaran, guru biasanya memfokuskan topik pembelajaran untuk meningkatkan aspek perkembangan anak. Dalam kegiatan tersebut, anak akan banyak belajar dan mengetahui hal yang belum mereka ketahui. Catron dan Allen dalam (Sujiono, 2009) mengemukakakn bahwa terdapat 6 aspek perkembangan anak usia dini, yaitu: kesadaran personal, pengembangan emosi, membangun sosialisasi, pengembangan komunikasi, pengembangan kognitif, dan pengembangan kemampuan motorik. Ke enam aspek tersebut dapat diterpakan 
Jurnal PG-PAUD Trunojoyo : Jurnal Pendidikan dan Pembelajaran Anak Usia Dini, Volume 7, Nomor 2, Oktober 2020 hal 9-22, ISSN : 2528-3553 (online), ISSN: 2407-4454 (print)

melalui pembelajaran di dalam kelas maupun di luar kelas. Adapun aspek perkembangan anak yang dicapai dalam melakukan pembelajaran melalui kegiatan outing class, antara lain:

a. Aspek Kognitif

Kemampuan kognitif merupakan kemampuan untuk memperoleh dan menggunakan pengetahuan dalam rangka memecahkan masalah serta beradapatasi dengan lingkungan (Knoblauch \& Woolfolk Hoy, 2008). Steve Stork dan Stephen W. Sanders (2008: 197-199) mengatakan aktivitas fisik sangat penting untuk pertumbuhan perkembangan secara keseluruhan pada anak. Mengoptimalkan penguasaan keterampilan dan sikap yang dapat menyebabkan perilaku yang lebih sehat dalam hidup, dan juga memfasilitasi perkembangan kognitif dan sosial, perkembangan fisiologis yang unik dan pengembangan neurologis terhadap anak usia dini. Dalam pengembangan kognitif menurut Woolfolk terdiri dari beberapa indikator yaitu 1) kemampuan mengingat dengan indikator menyebutkan dan menghubungkan, 2) kemampuan memahami dengan indikator mengelompokkan, membandingkan, dan memahami konsep bilangan, 3) kemampuan menerapkan dengan indikator memecahkan masalah sederhana.

b. Aspek Fisik Motorik

Gerakan motorik adalah suatu istilah yang digunakan untuk menggambarkan perilaku gerakan yang dilakukan oleh tubuh manusia (Hasanah, 2016). Menurut (Santrock, 2012: 145) mengungkapkan kemampuan motorik kasar (gross motor skill) meliputi kegiatan otot-otot besar seperti menggerakan lengan dan berjalan. Kegiatan outing class cukup efektif dalam mengoptimalkan psikomotorik anak.

Aspek fisik motorik merupakan aspek yang terdapat kaitannya dengan fisik atau pergerakan otot-otot. Adapun aspek fisik motorik yang didapat dari kegiatan outing class, antara lain: anakanak dapat memegang benda yang aman untuk dipegang oleh anak-anak dan merasakan.

c. Aspek Bahasa

Menurut Jamaris (2006) komunikasi dan Bahasa merupakan dua aspek yang sangat penting dalam kehidupan manusia. Tanpa dua kemampuan ini, manusia akan kesulitan untuk melakukan interaksi sosial. Bahasa dapat di definisikan sebagai bentuk kode sosial yang memiliki system yang digunakan untuk berkomunikasi.

Aspek bahasa merupakan aspek yang berkaitan dengan kemampuan berbicara anak-anak. Kegiatan outing class ini sangat cocok diterapkan pada anak-anak untuk mengasah kemampuan berbicara mereka. Adapun aspek bahasa yang dicapai dari kegiatan outing class ini antara lain: (a) anak-anak akan bertanya mengenai hal yang belum diketahui, (b) anak-anak akan belajar bercerita atau menceritakan kembali tentang apa yang mereka lihat maupun tentang pengalaman mereka saat melakukan kegiatan outing class di depan kelas atau di tempat yang sudah disediakan guru.

d. Aspek Seni

Fabiola Priscilla Setiawan (2010) menyatakan bahwa pendidikan seni berperan penting untuk merangsang perkembangan belahan otak bagian kanan anak. Otak kanan pada manusia lebih mengarak kepada keterampilan, seni, da kretivitas.

Aspek seni merupakan aspek yang memfokuskan pada tingkat kreativitas 
Jurnal PG-PAUD Trunojoyo : Jurnal Pendidikan dan Pembelajaran Anak Usia Dini, Volume 7, Nomor 2, Oktober 2020 hal 9-22, ISSN : 2528-3553 (online), ISSN: 2407-4454 (print)

anak-anak. Dalam kegiatan outing class anak-anak dapat mengkreasikan hal yang dilihat dari melakukan outing class. Adapun aspek seni yang dapat dicapai dari kegitan outing class antara lain: (a) anak dapat menggambarkan tentang hal yang telah di dapat dari kegiatan outing class (b) anak-anak belajar menempel gambar dari proses kegiatan outing class.

e. Aspek Nilai Agama dan Moral

Aspek nilai agama dan moral merupakan aspek yang berkaitan dengan adanya aturan-aturan yang telah ditetapkan oleh Tuhan. Adapun aspek nilai agama dan moral yang dapat dicapai dari proses kegiatan outing class adalah anak-anak belajar mensyukuri tentang apa yang sudah di ciptakan Tuhan. Bagi yang muslim dapat dengan mengucap Alhamdulillah dan bagi yang non muslim dapat menyesuaikannya. Menurut penelitian yang dilakukan oleh Adhani dan Nazarullail, (2019) mengatakan bahwa bermain di luar ruangan dengan konsep yang telah di tentukan dan di tetapkan dapat melatih tingkat kepatuhan anak usia dini terhadap aturan-aturan yang berlaku.

f. Aspek Sosial Emosional

Melalui kegiatan bermain anak-anak belajar interaksi sosial dengan teman sebayanya, dimana anak-anak belajar memahami, beradapatasi dengan kelompok dan berkomunikasi dengan orang lain (Latifah dan Sagala, 2015: 115). Aspek sosial emosional merupakan aspek yang berkaitan dengan nilai perilaku atau sikap anak terhadap sesuatu hal. Adapun aspek sosial emosional yang dapat di capai dari kegiatan outing class adalah anakanak belajar bersabar dan mengantri dalam proses belajar mengajar. Anakanak dapat bekerja sama untuk melakukan kegiatan yang membutuhkan kerja sama, misalnya pada bagian pemadam kebakaran anak-anak akan bekerja sama saat proses belajar memegang selang air damkarnya.

Kegiatan pembelajaran dengan menggunakan strategi outing class terdapat banyak hal yang diperoleh bagi perkembangan anak usia dini. Salah satu hal yang didapat dari melakukan kegiatan outing class adalah membantu meningkatkan aspek perkembangan anak. Aspek yang dapat dikembangkan dari kegiatan pembelajaran outing class tidak hanya satu aspek tetapi mencakup seluruh aspek perkembangan anak yakni aspek kognitif, fisik motorik, bahasa, seni, sosial emosional, serta nilai agama an moral. Jadi, kegiatan pembelajaran outing class merupakan pembelajaran yang efektif dilakukan.

Kegiatan outing class mendorong anak-anak berfikir kreatif dan juga meningkatkan potensi anak-anak pada aspek lain ketika berhadapan langsung dengan kehidupan dimasa depan. Anakanak akan lebih paham ketika yang dipelajari secara langsung dibandingkan dengan hanya melihat dan mendengarkan penjelasan di kelas. Melihat dan mendengarkan akan cepat dilupakan karena hanya membayangkan dan hanya ingat tanpa paham dan tahu apa yang ada. Pembelajaran yang dilaksanakan dengan mengunjungi tempat-tempat yang memiliki banyak pengetahuan baru memberikan manfaat yang besar bagi anak-anak. Karena anak-anak akan lebih memahami dan mengerti apa yang mereka telah lakukan.

Surakhman dalam Suryaningsih (2015), menjelaskan bahwa perjalanan wisata dalam rangka belajar merupakan bentuk pengalaman yang tidak dapat diabaikan begitu saja, karena karyawisata sesungguhnya memberikan kesempatan pengalaman kongkrit. Dengan anak di ajak untuk belajar 
Jurnal PG-PAUD Trunojoyo : Jurnal Pendidikan dan Pembelajaran Anak Usia Dini, Volume 7, Nomor 2, Oktober 2020 hal 9-22, ISSN : 2528-3553 (online), ISSN: 2407-4454 (print)

sambil bermain di tempat wisata maka kemauan anak untuk belajar akan semakin tinggi karena hakikat dari dunia anak adalah bermain. Sehingga, proses perjalanan wisata atau karya wisata dapat membantu guru dalam menyisipkan materi-materi pembelajaran kedalam kegiatan wisata

\section{SIMPULAN DAN SARAN}

Strategi pembelajaran outing class sangat berkontribusi dalam menumbuhkan minat belajar anak-anak. Pada era new normal, strategi ini cocok di terapkan di dalam pembelajaran karena dapat menghilangkan rasa jenuh anak-anak dengan syarat peserta didik wajib untuk tetap mematuhi protokol kesehatan. Dalam melaksanakan kegiatan outing class diperlukan juga sebuah strategi pembelajaran yang tepat untuk mencapai tujuan di inginkan. Kegiatan outing class memiliki banyak manfaat. Salah satu manfaat dari kegiatan outing class ini adalah menambah pengetahuan anak mengenai lingkungan sekitar serta membantu meningkatkan aspek perkembangan anak. Aspek perkembangan merupakan hal yang ingin dicapai dalam proses pembelajaran di lembaga PAUD. Hal itu menjadi pokok penting yang harus di capai. Adanya strategi pembelajaran juga mempermudah proses mengajar para guru kepada anak-anak. Jadi, saat mengajar guru tidak bingung tentang penyampaian materi atau kegiatan apa yang akan di ajarkan saat pembelajaran.

\section{DAFTAR PUSTAKA}

Adhani D.N. \& Nazarullail, F. 2019. Compliance (Perkembangan Moral) Pada Anak Usia Dini (5-6 Tahun) Melalui Bhanteng Dan Dhe Andheen (Permainan Tradisional Madura). Penelitian Mandiri Bangkalan: Universitas Trunojoyo Madura.

Anggraini, Wika. Nasirun, Muhammad Yulidesni. (2020). Penerapan Strategi $\begin{array}{llr}\text { Pemecahan } & \text { Masalah } & \text { dalam } \\ \text { Meningkatkan } & \text { Kemampuan } & \text { Kognitif }\end{array}$ pada Anak Kelompok B. Jurnal Ilmu Potensia. Vol. 5 No. 1 hal. 31-39.

Fabiola Priscilla Setiawan. (2010). Anak Cerdas Berkarakter Berkat Seni (Online). http://lifestyle.okezone.com. (Diakses 25 September 2020)

Indriana, D. (2011). Ragam Alat Bantu Media Pengajaran. Yogyakarta: Diva Perss,.

Geofani, Fisca Putri. (2018). Peningkatan Hasil Belajar Bahasa Indonesia Materi Menulis Dongeng dengan Metode OutingClass pada Siswa Kelas V SD Negeri 1 Majegan Kecamatan Tulung Kabupaten Klaten. Skripsi ini tidak diterbikan. Salatiga: Institut Agama Islam Negeri Salatiga.

Handayani, Oktarina Dewi. (2019). Ruang Publik Terpadu Ramah Anak (RPTRA) sebagai Sarana Sosialisasi bagi Anak. Jurnal Penelitian Dalam Bidang Pendidikan Anak Usia Dini. Vol. 8 No. 2.

Herliandry, L D. Dkk. (2020). Pembelajaran Pada Masa Pandemi Covid-19. Jurnal Teknologi Pendidikan. (Online). Vol. 22 No. 1.

Jamaris, M. (2006). Perkembangan dan Pengembangan Anak Usia Taman. Kanak-kanak. Jakarta: Gramedia.

Kiromi, Ivonne Hafidlatil. (2018). Pengaruh Metode Role Playing / Bermain Peran Terhadap Aspek Perkembangan Bahasa pada Anak. Jurnal Pendidikan. Vol. 4 No.1.

Latifah, U \& Sagala A.C.D. (2015). Upaya Meningkatkan Interaksi Sosial Melalui Permainan Tradisional Jamuran Pada Anak Kelompok B TK Kuncup Sari Semarang Tahun Pelajaran 2014/2015. Jurnal Penelitian PAUDIA. (Online).

Maryanti, Selfa. Kurniah, Nina. Yulidesni. (2019). Meningkatkan Kecerdasan Naturalis Anak Melalui Metode Pembelajaran Outing Class pada 
Jurnal PG-PAUD Trunojoyo : Jurnal Pendidikan dan Pembelajaran Anak Usia Dini, Volume 7, Nomor 2, Oktober 2020 hal 9-22, ISSN : 2528-3553 (online), ISSN: 2407-4454 (print)

Kelompok B TK Asyiyah X Kota Bengkulu. Jurnal Ilmiah Potensia. Vol. 4 (1). Hal. 22-31.

Maryanti, S. Dkk. (2019). Meningkatkan Kecerdasan Naturalis Anak Melalui Metode Pembelajaran Outing Class Pada Kelompok B TK Asyiyah X Kota Bengkulu. Jurnal Ilmiah Potensia. Vol. 4 No.1.

Muali, Chusnul. (2016). Konstruksi Strategi Pembelajaran Berbasis Multiple Intelligences Sebagai Upaya Pemecahan Masalah Belajar. Jurnal Pendidikan. Vol. 3, No. 2.

Pranandari, Ivania Agatha. (2020). Pengaruh Pembelajaran Outdoor Learning Terhadap Sikap Ilmiah dan Hasil Belajar Siswa Kelas VII SMP Negeri 2 Kalianda Tahun Pelajaran 2018/2019. Skripsi ini tidak diterbitkan. Bandar Lampung: Universitas Lampung.

Purossani, Adityo Gari. (2015). Pendampingan Pembelajaran Luar Sekolah Berbasis Wisata pada Anak SD di Gembira Loka Zoo. Skripsi ini tidak diterbitkan. Yogyakarta: Universitas Negeri Yogyakarta.

Rahayu, Rindang Rizky. Nurislaminingsih, Rizki. (tidak ada penulisan tahun). Analisis Kegiatan Outing Class sebagai Media Promosi di Taman Bacaan Masyarakat (TBM) Warung Pasinaon Kecamatan Bergas Kabupaten Semarang. Semarang: universitas diponegoro.

Ridwan, Muhammad. (2018). Penerapan Strategi Pembelajaran Outing Class untuk Meningkatkan Keterampilan Menulis Karangan Deskripsi pada Mata Pelajaran Bahasa Indonesia Siswa Kelas III di Madrasah Ibtidaiyah Nurul Ihsan Telanaipura Kota Jambi. Skripsi ini tidak diterbitkan. Jambi: Universitas Islam Negeri Sultan Thaha Saifuddin.

Rolina, Nolva. (tidak ada tahunnya). Memahami Psikologi Perkembangan
Anak bagi Pengembangan Aspek Seni Anak Usia Dini.

Rosyid, M H, dkk. (2019). Outdoor Learning. Belajar di Luar Kelas. Malang: Literasi Nusantara Abadi.

S, Patonah. SB. Rahardjo, Cari, dkk. (2018). Potensi Kegiatan Outing Class untuk Meningkatkan Lingkungan Kesadaran untuk Guru Pra-Jabatan Sekolah Dasar. International Journal of Pedadogy and Teacher Education. Vol. 2.

Santrock, J.W. 2012. Life-Span Development (Perkembangan Masa Hidup Edisi 13. Jilid 1, Penerjemah: Widyasinta,B). Jakarta: Erlangga.

Setiawan, Deny. (Tidak ada tahun). Peran Pendidikan Karakter dalam Mengembangkan Kecerdasan Moral. Medan: FIS Universitas Negeri Medan.

Sujiono, Y N. 2009. Konsep Dasar Pendidikan Anak Usia Dini. Jakarta: PT Indeks.

Suryaningsih. (2012). Penerapan Metode Karyawisata Dalam Upaya Meningkatkan Partisipasi Belajar IPS di Kelas V SD N Nanggulan Maguwoharjo. Artikel Journal PGSD.

Utami, Febriyanti. (2020). Pengaruh Metode Pembelajaran Outing Class terhadap Kecerdasan Naturalis Anak Usia 5-6 Tahun. Jurnal Obsesi: Jurnal Pendidikan Anak Usia Dini. Vol. 4.

Widiasari, Choiriyah. Almahi, Humaam. Prasetyoningrum, Dewi. dkk. (2019). Pengembangan Psikomotorik Peserta Didik Melalui Kegiatan Outing Class di RA Aisyiyah Bulakrejo 2, Sukoharjo. Buletin KKN Pendidikan. Vol. 1. No. 2.

Wulandari, H \& Purwanta, E. (2021). Pencapaian Perkembangan Anak Usia Dini di TK selama Pembelajaran Daring saat Pandemi Covid-19. Jurnal Obsesi : Jurnal Pendidikan Anak Usia Dini. (Online). Vol. 5 No.1.

Yansaputra, Galih. Pangestika, Rintis Rizkia. (2020). Peningkatan Sikap Sosial Positif 
Jurnal PG-PAUD Trunojoyo : Jurnal Pendidikan dan Pembelajaran Anak Usia Dini, Volume 7, Nomor 2, Oktober 2020 hal 9-22, ISSN : 2528-3553 (online), ISSN: 2407-4454 (print)

melalui Outing Class Permainan Tradisional Interaktif. Aksiologiya:

Jurnal Pengabdian Kepada Masyarakat.

Vol. 5 No. 2. 